Vig István

\title{
Az értékláncok és a növekedési modellek szerepe a gazdasági növekedésben
}

\section{The Role of Value Chains and Growth Models in Economic Growth}

Összefoglalás

A tanulmány megállapítja, hogy a kibocsátást, a jövedelmeket és a gazdasági növekedést nemcsak a termelési tényezők (tőke, munka, emberi tudás, természeti erőforrások) hozzák létre és tartják fenn, hanem abban kulcsszerepe van a vállalkozások üzleti- és a nemzetgazdaságok támogató növekedési modelljeinek is. A vállalkozók és a gazdaságstratégiai döntéshozók értékalkotásban játszott szerepe az üzleti és növekedési modelleken keresztül érvényesül. Elméleti értelemben az üzleti és növekedési modellek az értékláncok alapján értelmezhetők, amelyeket a mikroökonómiában már a hetvenes évek óta alkalmaznak. A vállalkozói szektoron belül a gazdasági növekedés létrehozásában az élenjáró és a követő vállalkozásoknak egyaránt fontos szerepe van. Az élenjárók radikálisan átalakítják vállalkozásaik üzleti modelljeit, amíg a követők az élenjárók üzleti modelljeit saját túlélésük érdekében adaptálják és ezzel a növekedési hatást kiszélesítik és egyben el is mélyítik.

Journal of Economic Literature (JEL) kódok: E61, F43, H54, L5 1, O1 1, O 12

Kulcsszavak: gazdasági növekedés, értéklánc, üzleti modell, gazdasági növekedési modell

VÍG IsTVÁN, közgazdász (vigistvanj@gmail.com). 


\begin{abstract}
Summary
The study establishes that outcomes, incomes and economic growth are generated and sustained not only by economic resources (capital, labour, human knowledge, natural resources) but also the business models of enterprises and the supporting development models of national economies play a key role. The role of entrepreneurs and policy makers in value creation prevails through business and growth models. In theoretical sense, business and growth models can be interpreted on the basis of value-chains, which have been applied in microeconomics since the seventies. Within the enterprise sector, national economic growth is fueled by both leading and following entrepreneurs. The leaders radically transform their business models, and the followers adapt them for the sake of their own survival, expanding and enhancing the growth effects of these models.
\end{abstract}

Journal of Economic Literature (JEL) codes: E61, F43, H54, L51, O 1 , O 12

Keywords: economic growth, value chain, business model, economic growth model

\title{
BEVEZETÉS
}

A hetvenes évektől a globális munkamegosztás jelentős átalakuláson ment keresztül. Ettől az évtizedtől kezdve az erőforrások felhasználásának optimalizációja globális szinten valósul meg és szélesedik ki. A globális üzleti folyamatok tevékenységeinek ellátása egyre több, adott esetben különböző országokban működő szereplő együttműködésével valósul meg. Ez a fajta munkamegosztás eltér az áruk és szolgáltatások kereskedelmére jellemző végtermék alapú munkamegosztástól. A korábbi egy, vagy néhány szereplős értékláncok helyett általánossá vált az outsourcing, legyen az nemzetgazdaságon belüli vagy kívüli, illetve a nemzetgazdaságok között a külföldi működőtőke kihelyező és befogadó, illetve relokációs üzleti modellek alkalmazása. A munkamegosztás új formájának létrejöttét a logisztikai-szállítási infrastruktúrák fejlődése és kiterjedése az olcsó globális anyagmozgatás biztosításával segíti elő, a globális vállalatirányítást pedig az információtechnológia fejlődése teszi lehetővé. A kormányzatok támogatják vállalataikat abban, hogy - az üzleti folyamatok különböző tevékenységeire specializálódva - globális értékláncaikat létrehozzák, megerősítsék, vagy azokhoz sikeresen kapcsolódjanak, továbbá hatékony üzleti modelleket alkalmazzanak.

\section{TERMELÉSI TÉNYEZŐK, ÉRTÉKLÁNGOK, ÜZLETI ÉS NÖVEKEDÉSI MODELLEK}

A munka, a tőke, a tudástőke, mint termelési tényezők nem elegendőek a kibocsátások, illetve a jövedelmek változásainak megértéséhez. Az új érték létrehozását az erőforrások mennyisége mellett jelentős súllyal meghatározzák a vállalati és a kormányzati gazdaságfejlesztési tevékenységek értékláncainak tulajdonságai, továbbá, hogy a vállalkozók mennyire hatékony üzleti modelleket képesek létrehozni és azt a kormányzatok gazdaságstratégiai tervezői meny- 
nyire hatékony nemzetgazdasági modellekkel támogatják.

A közgazdaságtudomány az elmúlt évtizedekben a hagyományosan értelmezett termelési tényezők (munka, tőke, természeti erőforrások) közé bevonta a tudástőkét, mint a gazdasági növekedés forrását. ${ }^{1}$ A vállalkozói tevékenységek termelési tényezők között való szerepeltetése azonban mindmáig csak elméleti értelemben történt meg. A vállalkozó értékalkotásban betöltött szerepét, a vállalkozói tevékenységet - az üzleti modell és annak értelmezési keretet adó értéklánc fogalmán keresztül - beemeljük az értékalkotó tényezők közé. Az üzleti modell és értéklánc vállalati szemléletű fogalmaival párhuzamosan a kormányzat gazdaságfejlesztési célú tevékenységére alkalmazzuk a növekedési modell és a nemzetgazdasági értelemben vett értéklánc fogalmát.

Az értékláncok az érték előallító tevékenységi struktúrákat jelentik, amelyek több lépésben és több tényező hatásaként mutatják be az üzleti-, szektorális- és nemzetgazdasági kibocsátások létrejöttének tényezőit. Az értékláncok legritkább esetben írhatók le úgy, mint egymást követő technológiai vagy üzleti folyamatok elemei - részben időben egymást követő, illetve egymással párhuzamosan hatást gyakorló elemei vannak. A lényeg azonban nem a struktúra időbeliségén vagy annak hiányán van, hanem azon, hogy minden tevékenység hozzájárul az értékalkotáshoz és az érték növeléséhez. Másképpen fogalmazva az értéklánc bármely elemének hiánya vagy nem kielégítő teljesítménye lehetetlenné teszi az érték létrejöttét vagy csökkenti annak mértékét. Az értéklánc az értékalkotó folyamatról, ebből adódóan az értékalkotás tényezőiről a termelési függvény munka, tőke és tudástőke elemeinél teljesebb, szélesebb körű képet mutat, mivel ez a tényező hangolja össze a termelési tényezők érvényesülését, ezért maga az értéklánc is értékalkotó tényező.

A vállalatok üzleti folyamatainak értékelésénél a nyolcvanas évektől az értéklánc vizsgálati elvet és módszert alkalmazzák (Porter, 1985). Az értéklánc fogalmát az eredetileg alkalmazott üzemi és üzemgazdasági célú felhasználásánál tágabban értelmezzük, például azáltal, hogy a vállalatfinanszírozást is beleértjük, továbbá a vállalati üzleti folyamatok mellett a kormányzat gazdaságfejlesztő tevékenységére is alkalmazzuk.

A tőke, mint termelési tényező vagy erőforrás, illetve a tőkefinanszírozás, mint tevékenység megkülönböztetendő fogalmak. A tőke azt az összeget, illetve hatáskifejtést jelenti, ami emelő hatást gyakorol a termelési és az eredmény mutatókra. A tőkével kapcsolatos finanszírozási tevékenység tartalma az adekvát finanszírozási eszközök kiválasztását, a megfelelő tőke volumenek meghatározását, a finanszírozás ütemezését, a kockázatok minimalizálását és még sok más kapcsolódó tevékenységet jelenti. Mindez a többi termelési tényezőre (munkaerő, tudás tőke) és az azokkal kapcsolatos tevékenységekre is vonatkozik.

Az értékláncok elemei különböző tulajdonságokkal rendelkeznek, ilyen tulajdonság a szolgáltatási színvonal, az értéklánc homogenitása és hosszúsága. A homogenitás azt jelenti, hogy az értéklánc elemeinek a tulajdonságai milyen mértékben térnek el egymástól. Az értéklánc hosszúsága az értéklánc elemei számát jelenti. Az értéklánc elemei szolgáltatási színvonalának, homogenitásának, az értékláncok hosszúságának, adott esetben a társadalmilag optimális hosszúságának, az elemek közötti átvitel hatékonyságának és különböző további jellemzőinek vizsgálata segíti a növekedési modellek gyenge pontjainak feltárását, hatékonyságának, kormányzati infrastruktúrákkal és szolgáltatásokkal történő javítását. A gazdasági folyamatok 
értékelése során fontos annak megismerése, hogy a növekedési hatás mennyire képes terjedni a gazdaság más szektorai felé, milyen fékek és szigetszerűségek korlátozzák hatásait.

Két értéklánc átlagos szolgáltatási színvonala lehet azonos amellett, hogy homogenitásuk jelentősen eltér egymástól. A magasabb homogenitású értéklánc azonban értékesebb. Az üzleti és gazdaságfejlesztési folyamatokban azonban paradox módon folyamatos a törekvés a homogenitás elérésére és az élenjáró vállalkozásoknál annak megbontására.

Az értékláncok és az elemeinek szolgáltatási színvonala és tulajdonságai többféle eszközzel is fejleszthetők, ezért a vállalkozók és a gazdaságstratégiai döntéshozók alternatívák közül választhatnak. A választott alternatívák a vállalkozások esetében az üzleti modellt, a kormányzati tevékenység esetén a növekedési modellt jelentik. A modellek a gazdasági döntéshozók „termékei”, amelyek meghatározzák az értékláncot alkotó tevékenységek és egyben a felhasznált termelési tényezők, erőforrások hasznosulását, annak eredményességét és hatékonyságát.

Az értékláncok elemeit egyszerre több modell is meghatározhatja. A gazdasági szereplők céljaiknak és preferenciáiknak megfelelően a modelleket változatos módon kombinálják, az üzleti célú szakirodalom több száz üzleti modellt azonosít. Az üzleti szféra szereplői között az értékalkotás tekintetében megkülönböztetjük az élenjáró és a követő vállalkozásokat. A nemzetgazdaságok növekedési modelljei szerves kapcsolatban állnak a makrogazdaságot felépítő szektorális és vállalati üzleti modellekkel.

A vállalati jövedelem, illetve kibocsátás függvényét az alábbi leegyszerűsített, stilizált formában írhatjuk fel:

$$
\Upsilon=f(K, L, K n, \mathcal{N}, E \text { (üzleti modell }))^{2}
$$

A nemzetgazdaságok szintjén - az üzleti döntésekhez hasonlóképpen - a gazdaságstratégiai döntéshozók döntéseikkel a nemzetgazdaság növekedési modelljét hozzák létre, illetve alakítják ki, ami alapján a nemzetgazdasági termelési/jövedelmi modell leegyszerűsítve az alábbi módon értelmezendő:

$$
\Upsilon=f(K, L, K n, \mathcal{N}, E \text { (növekedési modell)) }
$$

Az alábbi ábrán összefoglaljuk a fenti fogalmak kapcsolatait.

\section{1. ábra: Értékláncok és üzleti modellek hatása a gazdasági növekedésre}

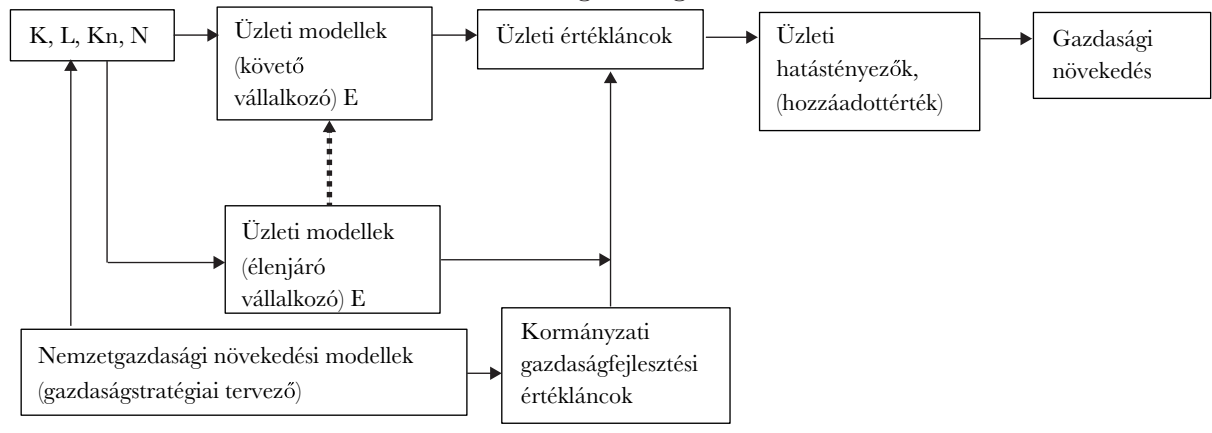

Forrás: saját szerkesztés 


\section{ÜZleti éRTÉKLÁnGOK, Mint AZ ÜZleti MODEllek ALAPJAI}

\section{Tevékenység transzferek és értékláncok}

A vállalati tevékenységek kihelyezése, illetve más vállalatok tevékenységének bevonása a gazdasági szereplők saját tevékenységeibe tevékenység transzfert jelent. A transzferált tevékenységek egy szélesebb körű tevékenységi lánc, az üzleti értéklánc elemei.

Az üzleti értéklánc az oktatásban gyökerezik. Néhány felzárkózó gazdaság az új technológiák létrehozását az oktatás megfelelő átalakításával indította el, általában a műszaki és természettudományokra, illetve a matematikára koncentrálva. A magasabb szintű oktatásban megszerzett mérnöki, természettudományi, matematikai tudást azonban csak a jól működő technológiai gazdaság képes a kutatásba átvinni, a kutatás eredményeit technológiákba, termékekbe, majd a termékeket vállalkozásokba strukturálni. A vállalatok megtanulták, hogyan kell a még meg sem lévő, jövőbeni kereslet víziója révén új termékeket létrehozni, majd ezek bázisán vállalatokat alapítani. Az értéklánc azonban itt még nem ér véget. A vállalkozásoknak működő üzleti modelleket szükséges kidolgozniuk. A termékeket értékesíteni kell, ahhoz piaci koncepcióra és marketingre van szükség, miközben a vállalati gazdálkodást - üzemgazdasági értelemben - a veszteség zónából a profitzónába kell áthelyezni. A piac nyújtotta növekedési lehetőségek eléréséhez a cégek saját tőkeakkumulációja általában nem elégséges, ezért a cégek megfelelő tőkeellátását kell biztosítani, adott esetben a cégeket fel kell készíteni tőzsdei megjelenésre vagy akvizícióra. S végül az eredményes üzletmenet, a hozzáadott érték hozza létre a nemzetgazdaság növekedési elemeit, a vállalkozások bővülő munka és profit jövedelmeit.

Az üzleti értékláncok a legegyszerűbb formájukban három elem-csoportból állnak: az általános és az üzleti-technológiai célú oktatásból, a technológiafejlesztési és a vállalkozásfejlesztési tevékenységekből. Minden egyes elem tovább bontható. Az alábbi táblázatban egy kifejlett vállalati értékláncot és az értéklánc elemhez tartozó kormányzati promóciós tevékenységeket láthatjuk:

\section{1. táblázat: Vállalati értékláncot alkotó tevékenységek}

\begin{tabular}{|c|c|c|c|c|c|c|}
\hline \multirow{2}{*}{$\begin{array}{l}\text { Értéklánc } \\
\text { elemek } \\
\text { (vektor) }\end{array}$} & \multicolumn{6}{|c|}{ Értéklánc elemek résztevékenységei (mátrix) } \\
\hline & 1. & 2. & 3. & 4. & 5. & 6. \\
\hline $\begin{array}{l}\text { Kutatás-fej- } \\
\text { lesztés }\end{array}$ & $\begin{array}{c}\text { Insource vagy } \\
\text { outsource } \\
\text { tevékenységel- } \\
\text { látás }\end{array}$ & $\begin{array}{c}\text { Szervezet } \\
\text { vagy megren- } \\
\text { delés }\end{array}$ & $\begin{array}{l}\text { Talentumok } \\
\text { keresése, } \\
\text { humán felté- } \\
\text { telek }\end{array}$ & $\begin{array}{l}\text { Kutatási és } \\
\text { termék port- } \\
\text { fólió }\end{array}$ & $\begin{array}{l}\text { Kutatás-fej- } \\
\text { lesztési esz- } \\
\text { közök }\end{array}$ & $\begin{array}{l}\text { Kutatás-fej- } \\
\text { lesztés minő- } \\
\text { sítés }\end{array}$ \\
\hline Beszerzés & $\begin{array}{l}\text { Igényfelmé- } \\
\text { rés, meg- } \\
\text { rendelések } \\
\text { elkészítése }\end{array}$ & $\begin{array}{l}\text { Szállítók } \\
\text { értékelése és } \\
\text { kiválasztása }\end{array}$ & $\begin{array}{c}\text { Árak és felté- } \\
\text { telek tárgya- } \\
\text { lása }\end{array}$ & $\begin{array}{l}\text { Megrendelé- } \\
\text { sek kibocsá- } \\
\text { tása }\end{array}$ & $\begin{array}{l}\text { Áruk fogadá- } \\
\text { sa és ellenőr- } \\
\text { zése }\end{array}$ & $\begin{array}{c}\text { Számlák } \\
\text { jóváhagyása } \\
\text { és fizetése, } \\
\text { nyilvántartás }\end{array}$ \\
\hline
\end{tabular}




\begin{tabular}{|c|c|c|c|c|c|c|}
\hline \multirow{2}{*}{$\begin{array}{l}\text { Értéklánc } \\
\text { elemek } \\
\text { (vektor) }\end{array}$} & \multicolumn{6}{|c|}{ Értéklánc elemek résztevékenységei (mátrix) } \\
\hline & 1. & 2. & 3. & 4. & 5. & 6. \\
\hline $\begin{array}{l}\text { Üzemi tevé- } \\
\text { kenységek }\end{array}$ & $\begin{array}{l}\text { Technológia } \\
\text { tervezés }\end{array}$ & $\begin{array}{l}\text { Termelésirá- } \\
\text { nyítás }\end{array}$ & $\begin{array}{l}\text { Gyártórend- } \\
\text { szer irányítás }\end{array}$ & $\begin{array}{l}\text { Minőségbiz- } \\
\text { tositás }\end{array}$ & Készletezés & 0 \\
\hline $\begin{array}{l}\text { Elosztási } \\
\text { logisztika } \\
\text { (disztribú- } \\
\text { ció) }\end{array}$ & $\begin{array}{l}\text { Betárolás a } \\
\text { készárurak- } \\
\text { tárba }\end{array}$ & $\begin{array}{l}\text { Csomagolás, } \\
\text { egységrako- } \\
\text { mányképzés }\end{array}$ & Kitárolás & $\begin{array}{c}\text { Készletek } \\
\text { nyilvántartása }\end{array}$ & 0 & 0 \\
\hline Marketing & Piackutatás & $\begin{array}{l}\text { Cél-szegmen- } \\
\text { sek értékelése }\end{array}$ & $\begin{array}{c}\text { Javaslatok } \\
\text { azonosítása } \\
\text { szegmensekre }\end{array}$ & $\begin{array}{l}\text { Értékesítés és } \\
\text { elosztás }\end{array}$ & $\begin{array}{l}\text { Brandfej- } \\
\text { lesztés }\end{array}$ & $\begin{array}{l}\text { Hirdetés és } \\
\text { promóció, } \\
\text { árazás }\end{array}$ \\
\hline Értékesítés & $\begin{array}{l}\text { Termékbemu- } \\
\text { tatás, eladási } \\
\text { programok }\end{array}$ & $\begin{array}{c}\text { Üzletkötés, } \\
\text { ügyfélkapcso- } \\
\text { lat menedzs- } \\
\text { ment }\end{array}$ & $\begin{array}{l}\text { Nyomonkö- } \\
\text { vetés }\end{array}$ & $\begin{array}{l}\text { Értékesítés } \\
\text { finanszírozás }\end{array}$ & $\begin{array}{l}\text { Értékesítési } \\
\text { hálózat }\end{array}$ & Panaszkezelés \\
\hline $\begin{array}{l}\text { Értékesítés } \\
\text { utáni szol- } \\
\text { gáltatások }\end{array}$ & $\begin{array}{l}\text { Garancia } \\
\text { feltételek, } \\
\text { hálózat mű- } \\
\text { ködtetése }\end{array}$ & $\begin{array}{l}\text { Alkatrész } \\
\text { ellátás }\end{array}$ & Avuláskezelés & Javítás, csere & $\begin{array}{c}\text { Karbantartási } \\
\text { szerződések }\end{array}$ & 0 \\
\hline $\begin{array}{l}\text { Humán } \\
\text { kapcsolatok }\end{array}$ & $\begin{array}{l}\text { Toborzás, } \\
\text { talentumok } \\
\text { keresése }\end{array}$ & $\begin{array}{l}\text { Tréningek, } \\
\text { teljesítmény- } \\
\text { értékelés }\end{array}$ & Motiválás & Kompenzáció & $\begin{array}{l}\text { Munka } \\
\text { kapcsolatok } \\
\text { fenntartása }\end{array}$ & $\begin{array}{l}\text { Egészség, jólét } \\
\text { és biztonság, } \\
\text { munkajognak } \\
\text { megfelelés }\end{array}$ \\
\hline $\begin{array}{l}\text { Finanszíro- } \\
\text { zás }\end{array}$ & $\begin{array}{c}\text { Kiadások és } \\
\text { bevételek nyil- } \\
\text { vántartása és } \\
\text { előrejelzése }\end{array}$ & $\begin{array}{c}\text { Kockázat me- } \\
\text { nedzsment }\end{array}$ & $\begin{array}{l}\text { Cash posi- } \\
\text { tioning és } \\
\text { cash-flow } \\
\text { előrejelzés }\end{array}$ & $\begin{array}{l}\text { Rövidlejáratú } \\
\text { befektetés és } \\
\text { finanszírozás }\end{array}$ & $\begin{array}{l}\text { Kifizetések } \\
\text { és készpénz- } \\
\text { gyújtés }\end{array}$ & $\begin{array}{l}\text { Beruházásfi- } \\
\text { nanszírozás }\end{array}$ \\
\hline $\begin{array}{l}\text { Menedzs- } \\
\text { ment }\end{array}$ & $\begin{array}{c}\text { Területek } \\
\text { irányításának } \\
\text { összehango- } \\
\text { lása }\end{array}$ & $\begin{array}{l}\text { Üzleti terve- } \\
\text { zés, irányítás, } \\
\text { ellenőrzés }\end{array}$ & $\begin{array}{l}\text { Operatív és } \\
\text { fejlesztési } \\
\text { döntések }\end{array}$ & $\begin{array}{l}\text { Üzleti straté- } \\
\text { gia és üzleti } \\
\text { modellek, } \\
\text { döntések }\end{array}$ & $\begin{array}{l}\text { Szervezet- } \\
\text { építés }\end{array}$ & $\begin{array}{c}\text { Stratégiai } \\
\text { projektek, } \\
\text { akciók mene- } \\
\text { dzselése }\end{array}$ \\
\hline
\end{tabular}

Forrás: saját szerkesztés

\section{Üzleti modellek és fejlődésük}

Az értéklánc egy-egy elemét érintő tevékenység többféle modell, módszer, eszköz révén is megvalósítható. Az üzleti modell a vállalkozó által a tevékenység ellátás megvalósítási alternatívái, eszközei, módszerei közötti választást jelenti, amely az értéklánc egy-egy vagy több, akár annak összes elemét is érintheti. Az alternatívák egy részét a vállalkozó eleve kizárja, másokat mérlegel vagy más alternatív megoldási lehetőségekkel kombinálja. Fennáll annak a lehetősége is, hogy a vállalkozó valamely értéklánc elemet saját tevékenység helyett idegen tevékenységgel lát el (outsourcing).

A vállalkozó által az értéklánc egy-egy tevékenységének ellátására választott eszköz, módszer az üzleti modell eleme, ennek megfelelően beszélhetünk kutatás-fejlesztési, beszerzési, 
értékesítési vagy finanszírozási modellről. Az összes tevékenységre vonatkozó üzleti modell elem adja magát az üzleti modellt.

2. táblázat: Üzleti modell, elemi modell és választható alternatívák

\begin{tabular}{|c|c|c|c|}
\hline $\begin{array}{l}\text { Üzleti modell elemei, } \\
\text { elemi modellek }\end{array}$ & 1. alternatíva & 2. alternativa & 3. alternatíva \\
\hline $\begin{array}{l}\text { Kutatás-fejlesztési } \\
\text { modell }\end{array}$ & $\frac{\text { Insource kutatás-fejlesztési }}{\underline{\text { tevékenység* }}}$ & $\begin{array}{c}\text { Outsource kutatás-fejlesz- } \\
\text { tési tevékenység (licence, } \\
\text { akvizíció) }\end{array}$ & $\begin{array}{l}\text { Reverse engineering, má- } \\
\text { solás, imitation, adaptálás }\end{array}$ \\
\hline Beszerzési modell & $\begin{array}{l}\text { Hagyományos beszerzési } \\
\text { folyamat (igényfelmérés, } \\
\text { szállítók kiválasztása, meg- } \\
\text { rendelés) }\end{array}$ & $\frac{\text { Egyedi kapcsolat az alkat- }}{\frac{\text { részellátókkal, termelési }}{\underline{\text { tervek megosztása }}}}$ & 0 \\
\hline $\begin{array}{l}\text { Üzemi tevékenységek } \\
\text { modell }\end{array}$ & $\begin{array}{l}\begin{array}{c}\text { Vegyes (automatizált és } \\
\text { manuális) gyártósorok, }\end{array} \\
\text { integrált termelés irányítás }\end{array}$ & Egyedi előállítás & 0 \\
\hline Marketing modell & $\begin{array}{c}\text { Árazásra, minőségre } \\
\text { optimalizált marketing } \\
\text { eszközök }\end{array}$ & $\begin{array}{l}\text { Nincs marketing, helyette } \\
\text { PR tevékenység van }\end{array}$ & 0 \\
\hline Értékesítési modell & $\begin{array}{l}\frac{\text { Saját értékesítési hálózat }}{\text { és kiskereskedelmi tevé- }} \\
\underline{\text { kenység ellátása }}\end{array}$ & $\begin{array}{l}\text { Szerződött értékesítési } \\
\text { hálózat (outsourcing) }\end{array}$ & $\underline{\text { Direkt értékesítés (online) }}$ \\
\hline $\begin{array}{l}\text { Értékesítés utáni szol- } \\
\text { gáltatások modell }\end{array}$ & Saját szolgáltatási hálózat & Franchise szerviz hálózat & 0 \\
\hline Finanszírozási modell & $\begin{array}{l}\text { Zárt részvénytársaság } \\
\text { tőkeemelés, új partnerek } \\
\text { bevonása }\end{array}$ & Tőzsdei bevezetés, IPO & $\begin{array}{l}\text { Mezzanine finanszírozás } \\
\text { (pl.: konverziós kötvény) }\end{array}$ \\
\hline
\end{tabular}

*Esetünkben az aláhúzott a választott alternativa

Forrás: saját szerkesztés

Az elmúlt százötven év ipar- és szolgáltatásfejlődése meghatározó hatást gyakorolt az üzleti modellek fejlődésére. Ez az evolúció (Dallos, 2021) az 1900-as évek első felében a tömeggyártás megteremtésére, míg az ötvenes és a kilencvenes évek között az elosztás és a hatékony marketing fejlesztésére irányult. A kilencvenes évekkel az internet technológia adott lehetőséget az e-commerce modellek alkalmazására. Napjainkban a fogyasztó központú, adatbázisok irányította előrejelző modellek kerültek az üzleti modellalkotás középpontjába. Néhány meghatározó - sok esetben közismert - üzleti modellt az alábbiakban felsorolásszerüen ismertetünk:

- A tradicionális üzleti modellek (Maryville, 2021) közül a legismertebbek a termelés-értékesítés lánc gyártói, nagykereskedői és kiskereskedői üzleti modelljei.

- A franchise, mint értékesítési modell magában foglalhatja mindhárom fenti modellt, továbbá növekedési modellként is szolgál.

- A múlt század első felének meghatározója a tömegtermelés üzleti modell, amely a termékek előállítását nagy volumenben, szabványosított eljárásokon keresztül, az egység termékre jutó kiadások alacsony szintjén biztosítja. Az üzemi műveletek stan- 
dardizáltak, részletes technológiai utasításokon alapulnak. A folyamatok nagyfokú automatizáltsága a dolgozók részéről nem igényel magas szakmai kvalifikációt, a „szaktudást a szerszám hordozza”.

- A múlt század második felének meghatározó modellje a fejlett logisztikán alapuló just-in-time gyártásszervezés, amelyet a hatvanas és a hetvenes években alapoztak meg. Az üzleti modell eredményeként az üzemi folyamatok válaszidői a beszerzéstől az értékesítésig lecsökkentek, aminek következtében mérséklődött a készletszint és a raktárkapacitás igény, jelentősen javítva a beruházási hatékonyságot.

- A hatvanas évektől az értékesítés elősegítésére jött létre a legtöbb üzleti modell (Fourweekmba, 2021). Az internet technológia létrejötte gyökeresen alakította át a vállalatok fogyasztókkal való kapcsolatait, az e-commerce üzleti modellnek számos típusa ismert.

- Az aukció alapú modellek biztosítják, hogy a termék a legerősebb verseny mellett kerüljön értékesítésre. A modell régi múltra tekint vissza, azonban az internet technológia használati területét kiszélesítette.

- A technológiafejlesztés terén a legelterjedtebb modell, a vállalati alapú kutatás-fejlesztés mellett a néhány évtizedes múlttal rendelkező kockázati tőke-startup modell és az ún. „reverse engineering” említhető meg.

- A vállalat- és projektfinanszírozási modellek a tradicionális bankhiteltől, a tőzsdei finanszírozáson és a lízingen keresztül a különféle vegyes „mezzanine” technikáig széles palettán jelennek meg és igen differenciáltak. A szerves növekedést meghaladó gyors növekedés elérése egyrészt a növekedési modellek (M\&A) sajátja, másrészt más tulajdonságra optimalizált modellek is biztosíthatják (FDI, franchise).

\section{Az üzleti modellek hatáskifejtése}

Az üzleti modellek egy részének hatása csak az értéklánc egy elemére irányul (például: a legtöbb értékesítési modell), a modellek kisebb száma sokszereplős összetettebb szisztémákat, szervezeti rendszereket alkot (például: startup-kockázati tőke, franchise, külföldi működőtőke kihelyező modellek), összetettebb hatásokkal. A vállalkozók üzleti céljaik megvalósítása érdekében a modelleket változatos módon kombinálják. Az üzleti modellek az értéklánc elemeken keresztül hatást gyakorolnak a vállalatok piaci, bevételi, költség, eredmény, tőkelekötési, likviditási és még számos egyéb pozíciójára, ezeken keresztül a hozzáadott értékre. A hatásoknak szűkebb és tágabb köre, illetve közvetlenebb és közvetettebb formái is lehetségesek. A sokszereplős összetettebb modelleket egész szektorok kormányzati növekedési modelljeiként is alkalmazzák.

Az alábbi táblázat az egyes üzleti modellek értéklánc elemekre irányuló hatásait mutatja be. 
3. táblázat: Üzleti modellek hatásai az értéklánc elemekre

\begin{tabular}{|c|c|c|c|c|c|c|c|c|c|c|}
\hline Üzleti modell & 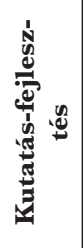 & 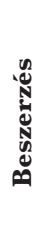 & 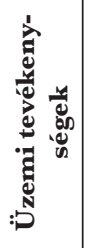 & 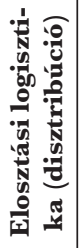 & 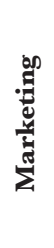 & 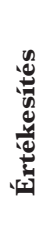 & 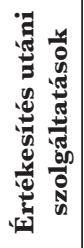 & 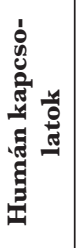 & 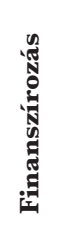 & 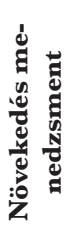 \\
\hline Gyártó & + & + & + & + & & & + & + & + & \\
\hline Nagykereskedő & & & & & + & + & & & & \\
\hline Kiskereskedő & & & & & + & + & & & & \\
\hline Franchise szervezet & + & + & + & + & + & + & + & + & + & + \\
\hline Tömegtermelés & & + & + & + & & & & & & \\
\hline Just in time & & + & + & + & & & & & & \\
\hline Kockázati tőke - startup & + & & & & & & & & + & \\
\hline Reverse engineering & + & & & & & & & & & \\
\hline Direkt értékesítés & & & & & + & + & & & & \\
\hline E-commerce & & & & & & + & & & & \\
\hline Aukció & & & & & & + & & & & \\
\hline Bankhitel & & & & & & & & & + & \\
\hline Tőzsde & & & & & & & & & + & + \\
\hline Lízing & & & & & & + & & & + & \\
\hline
\end{tabular}

Forrás: saját szerkesztés

Élenjárók és követôk, mint a gazdasági növekedés motorjai

Az üzleti modell innovációknak a termék és az előállítás technológiája, a termék nyereséges előállíthatósága, megtakarítások realizálása, illetve a maximális értékesítési potenciál elérése áll a középpontjában. Az üzleti modell adja meg a termék üzleti létezésének jogosultságát és súlyát, vele együtt az értékképző erejét a növekedési folyamatban.

Az új üzleti modelleket létrehozó vállalkozók - az élenjárók - innovációinak egy részét a követő vállalatok átveszik és alkalmazzák. Az adaptáció a gazdasági növekedés szempontjából alapvető fontosságú, mivel az hozza létre a hatások egész szektorokra kiterjedő érvényesülését, egyben a hatások megsokszorozódását. Az adaptáció a nemzetgazdasági GDP bővülésének feltétele, a gazdasági növekedés szélességét erősíti. A növekedés szélessége azt mutatja meg, hogy a gyors növekedés a GDP milyen százalékában nyilvánul meg.

Egy-egy szektor általában vett technológiai és tudás színvonalát a követő vállalatok technológiai és tudás státusza jeleníti meg, amely a követőket alkalmassá teszi az élenjáró üzleti modellek adaptációjára. A követő vállalkozók adaptációs képességéhez mérve az élenjáró vállalkozók képesség tőkéje alapozza meg a vállalkozásaik extra növekedését. Az élenjárók elő- 
nyét a szabadalmi védelem ereje, a követők másolási-adaptálási nehézségei, illetve az élenjárók folyamatos innovációi tartósíthatják. A követők jelenítik meg az erőforrások, az élenjárók az erőforrások és az üzleti modelljük által determinált növekedési színvonalat.

Két ismert nagyvállalat esetében az alábbi módon történt meg új üzleti modelljeik létrehozása és ezzel elszakadásuk a szektorra jellemző üzleti modellektől.

- A Dell Computers sikereit az ellátási láncban és a gyártásban történt innovációinak köszönhette (Case study: Dell). A vállalat direkt értékesítési stratégiát választott és először használt online értékesítő platformot. Ezzel szemben minden más személyi számítógép gyártó kereskedelmi értékesítési helyeken előre kiépített és összeszerelt termékeket értékesített. A Dell széleskörű rendszer kiépítési választékot ajánlott a vásárlóinak - az üzleti modelljéből származó megtakarításainak köszönhetően - igen kedvezményes áron. A direkt értékesítésnek köszönhetően a piaci adatok széles adatbázisát is létrehozta, amelyet a keresleti trendek előrejelzésére használt. Mivel saját alkatrészellátást nem épített ki, ezért az alkatrészgyártókkal termelési terveit és értékesítési előrejelzéseit megosztotta. Az alkatrészeket a gyártók az alacsony készletszint érdekében ,just-in-time" rendszerben szállították.

- A Tesla Inc. nem az elektromos autót találta fel, hanem annak nyereséggel történő gyártásának és értékesítésének üzleti modelljét. A modell jelentősen eltér a hagyományos autógyártók üzleti modelljétől. A vállalat direkt értékesítést folytat, ellentétben a hagyományos gyártókkal, amelyek az értékesítésre franchise partnereket bíznak meg. A Tesla az értékesítésre bemutatótermek és galériák nemzetközi hálózatát hozta létre, amelyen keresztül - a fogyasztó vásárlási magatartásának gyors és közvetlen megszerzésével - a termékfejlesztés gyorsaságát is elősegíti. A vásárló online módon is testre szabhat és megrendelhet egy gépkocsit. A Tesla világszerte többszáz ún. Service Plus központtal rendelkezik, amelyeknél az értékesítést kombinálja szerviz szolgáltatásaival. A mobil szerelők otthonról szolgálják ki a járműveket, bizonyos típusok adatait táveléréssel is vizsgálhatják és néhány problémát online javíthatnak. A vállalat versenytársaihoz képest több éves előnyben van a fejlesztésekhez szükséges adatok gyüjtésében. A Tesla korábban kelet-ázsiai gyártók akkumulátorait építette be autóikba, jelenleg a saját gyártást saját kutatás-fejlesztési bázisára helyezi át, továbbá célkitűzései között szerepel a teljesen automatizált termelés megteremtése. A vállalat technológiai előnye és felfutó termelése veszélyt jelent a legnagyobb autógyártók számára is.

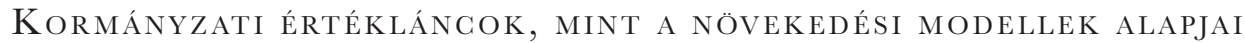

\section{Kormányzati gazdaságfejlesztési értékláncok}

Az üzleti modellek működési feltételeinek biztosításában, a nemzetgazdasági vagy szektorális növekedési modellek létrehozásában, fejlesztésében a kormányzati vállalkozásfejlesztési tevékenységnek kulcsszerepe lehet. A növekedésre képes szektorok létrehozásához vagy azok működési feltételei javitásához a nemzetgazdaságnak stratégiára, programokra és kormányzati intervenciókra, szabályozásra van szüksége. Az üzleti folyamatok stimulálása céljából a kor- 
mányzatoknak fel kell ismerni, hogy az értékláncok mely szakaszaiban, milyen eszközökkel, mikor és milyen időtartamban van helye a kormányzati beavatkozásnak és azt a kormányzatnak milyen szerepkörben kell megtennie.

A kormányzati szerepvállalást a kormányzati támogató célú értékláncok segítik elő, amelyek részben a vállalati értékláncok elemeit ölelik fel, az oktatásra, a kutatás és vállalkozásfejlesztésre, a kormányzati infrastruktúrákra, továbbá a gazdasági, jogi, adó- és elszámolási szabályozásra irányulnak.

A húzóágazatok fejlesztése kiemelkedően fontos, mivel növekedésük többszörösen meghaladhatja a nemzetgazdaság egészének növekedését. Néhány üzleti modell egész szektorok növekedési modelljévé vált (startup-kockázati tőke, külföldi működőtőke kihelyező modellek). A globális tevékenységek optimalizációja következtében a nemzetgazdasági növekedési modellek makrogazdasági szerepre is szert tehetnek, emiatt a makrogazdasági jellemzők leírásához is nélkülözhetetlenné válhatnak (OECD, 2019).

Ne feledjük el azt, hogy a piac kontrollálta szektorokban kifejlesztett értékláncok bizonyos elemeit és technikáit - ha jelentős késéssel is - a kisebb üzleti cégeknél és az üzlettől távol eső területeken is, például a közszolgáltatásokban is adaptálják, javítva ezzel a gazdaság egészének növekedési lehetőségeit.

\section{Nemzetgazdasági növekedési modellek}

Az elmúlt évtizedekben sikeres felzárkózást végrehajtott gazdaságok által alkalmazott növekedési modellek és eljárások könnyebben megfejthető képet adnak a növekedés tényezőiről, mint a szervesen fejlett gazdaságok lassan lejátszódó evolutív folyamatai. Izrael, Finnország és Dél-Korea tudásintenzív, Írország és Szingapúr erőforrás-intenzív, külföldi működőtőke bevonó stratégiát alkalmazott. Kína intenzív fejlődésének periódusában megváltoztatta célmodelljét, a külföldi működőtőke bevonó erőforrás-intenzívről a tudásintenzív modellre váltott át.

A 4. sz. táblázat a növekedési modellek alkalmazott termelési tényező és tevékenység-struktúráját mutatja be.

Külföldi működőtőke kihelyező modell (autonóm gazdaságok): A külföldi működőtőke kihelyező gazdaságok jól ellátottak tőkével, tudástőkével, magas szintű munkaerővel, általában szűkében vannak az alacsonyabb szintű munkaerőnek, illetve természeti kincseknek. A saját technológiás tudásintenzív gazdaságok szereplői a kutatástól és termékfejlesztéstől, a termelésen, az értékesítésen és az értékesítést követő szolgáltatások biztosításán át a finanszírozásig az értéklánc összes tevékenységét irányítják, de azokat nem feltétlenül végzik is. A modell domináns gazdaságai a működőtőke meghatározó kihelyezői más fejlett, illetve feltörekvő gazdaságokba. 
4. táblázat: Növekedési modellek termelési tényező és tevékenység szerkezete (tevékenység mintázat)

\begin{tabular}{|c|c|c|c|c|c|c|}
\hline Növekedési modell típusok & & 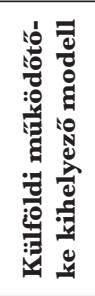 & 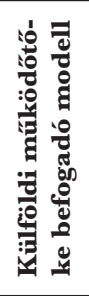 & 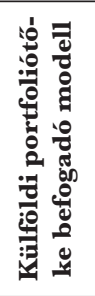 & 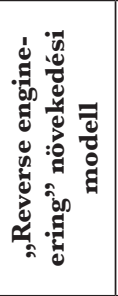 & 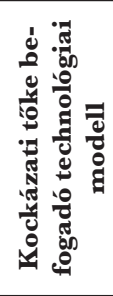 \\
\hline \multicolumn{7}{|c|}{ Termelési tényező szerkezet } \\
\hline Jelölése & & FDI $^{\text {out }}$ & $\mathrm{FDI}^{\text {in }}$ & $\mathrm{FPI}^{\text {in }}$ & $\mathrm{RE}$ & $\mathrm{VC}^{\text {in }}$ \\
\hline Töke $(\mathbf{K})$ & & $\mathrm{x}$ & & & $\mathrm{X}$ & \\
\hline Tudástőke (Kn) & & $\mathrm{X}$ & & $\mathrm{X}$ & & $\mathrm{X}$ \\
\hline Munkaerő (L) & & $\mathrm{X}$ & $\mathrm{x}$ & $\mathrm{X}$ & $\mathrm{x}$ & $\mathrm{x}$ \\
\hline Vállalkozó (E) & & $\mathrm{X}$ & & $\mathrm{X}$ & $\mathrm{X}$ & $\mathrm{X}$ \\
\hline \multicolumn{7}{|c|}{ Tevékenység szerkezet } \\
\hline Középfokú oktatás & \multirow{2}{*}{$\begin{array}{c}\text { Okta- } \\
\text { tás }\end{array}$} & + & + & + & + & + \\
\hline Szakirányú felsőoktatás & & + & & + & + & + \\
\hline Új technológiák létrehozása & \multirow{3}{*}{ 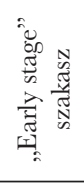 } & & & & & + \\
\hline Termékek létrehozása & & & & & & + \\
\hline $\begin{array}{l}\text { Technológiai piacon értékesítés/ vá- } \\
\text { sárlás }\end{array}$ & & + & & & & + \\
\hline Vállalati kutatás-fejlesztés & \multirow{12}{*}{ 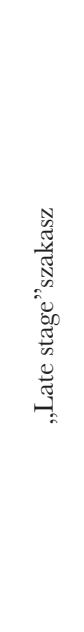 } & + & & + & & \\
\hline Beszerzés & & + & & + & + & \\
\hline Üzemi tevékenységek & & + & + & & & \\
\hline Elosztás (disztribúció) & & + & & + & + & \\
\hline Marketing & & + & & + & + & \\
\hline Értékesítés & & + & & + & + & \\
\hline Értékesítés utáni szolgáltatások & & + & & + & + & \\
\hline $\begin{array}{l}\text { Funkcionális tevékenységek (humán és } \\
\text { pénzügy, stb.) }\end{array}$ & & + & + & + & + & \\
\hline Tőkekihelyezés (múködő, portfolió) & & + & & & & \\
\hline Tőkebevonás (múködő, portfolió) & & & + & + & & + \\
\hline Belső finanszírozás & & & & & + & \\
\hline Menedzsment & & + & & + & + & \\
\hline
\end{tabular}

FDI - Foreign Direct Investment, FPI - Foreign Portfolio Investment, RE - „Reverse engineering”, VC e.s. - Venture Capital early stage

Forrás: saját szerkesztés 
A működőtőke kihelyező modellnél a tőke már nem független tényezőként, autonóm módon (például tőzsdei tőkeemelés formájában), hanem a technológiai-tudás komponensekkel, úgy is mondhatjuk ,előregyártott, kapcsolt csomagok”-ban, a különböző üzleti-nemzetgazdasági modellek építőelemeiként áramlik.

Külföldi működőtőke befogadó modell: A működőtőke intenzív (FDI) befogadó modellnél az értéklánc egy szakaszát, mint munkaerőigényes tevékenységet egy másik országban végzik el, az ott jellemző alacsonyabb munkaerő költségek mellett vagy egy a kibocsátó gazdasághoz hasonlóan fejlett gazdaságban végzik el, az ország vagy a régió piacaihoz való hozzáférés elősegitése céljából. A tőkebefogadó gazdaság nem hoz létre új technológiát és terméket, a gazdaság munkaerejével kapcsolódik be a kibocsátó nagyvállalatok értékláncaiba. Ezt a modellt, ha magas szintű technológiai tevékenységre irányul, valójában a tevékenységek statisztikai besorolása alapján tekintjük technológiai modellnek - ténylegesen munkaerőgazdaság - alacsony kutatás-fejlesztési kiadásokkal. ${ }^{3}$ Az FDI befogadó modell az értékláncokat irányító kihelyezőtől függő jellege miatt nem autonóm gazdasági modell. Írország a külföldi működőtőke befogadó modellt minta értékűen és sikeresen alkalmazta, ennek eredményeként 1987 és 2000 között a legfejlettebb gazdaságok közé emelkedett (Ireland, 2014; Barry - O’Mahony, 2006; Barry - Görg - McDowell, 2001). A modellt a világ összes részén alkalmazzák, néhány esetben a technológiai gazdaságba történő átmenet modelljét jelenti.

Külföldi portfóliótőke befogadó modell: Egyes országoknak nincsen szükségük technológia bevonásra, mivel rendelkeznek vele. Szükségük van azonban a vállalatok növekedéséhez, terjeszkedéséhez pénzügyi forrásokra, amelyet elsősorban tőzsdei részvénykibocsátásra alapozzák. Finnország hagyományos ágazatok dominálta gazdaságát 1993 és 2000 között - a magas bér- és adókörnyezet fenntartása mellett - technológiai gazdaságba fordította át (Hirvonen, 2004; Kiander, 2004; Paija, 2000). Az egy-vállalatos, egy-szektoros finn technológiai modell a tőkehiányt tőzsdei forrásszerzéssel oldotta fel, amelyet jellemzően a szervesen fejlett gazdaságok tőkepiacai biztosították.

„Reverse engineering” és belső finanszírozás alapú növekedési modell: Dél-Korea gyors növekedési szakaszának kezdetekor nem rendelkezett saját technológiával. A technológiai tudást külföldi működőtőke bevonása nélkül saját előállításra alapozta (Kim, 1997; Fakir, 2016). A vállalati tőkeakkumulációt kezdetben a külföldi támogatások (Faludi, 2005), később az alacsony munkabérek tették lehetővé. Az ország 1963 és 2002 között - alacsony bér- és adó környezetben - hagyományos, majd modern technológiai gazdaságot hozott létre (CIA, 1983). A modell sarokpontjai voltak a fejlesztéseket és export elvárásokat megfogalmazó és támogatásokat biztosító kormányzati gazdaságirányítás, a magántulajdonon alapuló chaebolok végrehajtó és vállalkozó szerepe, az állam és a vállalatok közötti középtávú indikatív tervek, a bankok, mint a kedvezményes kormányzati hitelek közvetítői és a vállalati kontroll megvalósítói, késői fázisú termékfejlesztés, licenszvásárlás és „reverse engeneering”4 formájában, az alacsony bérek. Az egyszerűbb termékeket lemásolták, az összetettebbeknél licenszeket vásároltak, illetve technológiával rendelkező főként külföldi, csődhelyzetben lévő cégeket vásároltak fel. Amennyiben licensz vásárlásra nem volt mód, visszatértek az egyedüli rendelkezésre álló eszközhöz, a másoláshoz, más néven az ún. „reverse engineering”-hez (Kim - Westney, 1999). Ezt a módszert gazdasága felzárkóztatására jelenleg Kína alkalmazza. 
Kockázati tőke befogadó technológiai modell: Az „early stage” ${ }^{5}$ technológiai fejlesztés (OECD, 2015) során a tevékenységek végső produktumai olyan kísérleti stádiumban lévő technológiák és termékek, amelyek piaci értelemben ígéretesek, de hogy bevételt hozó termék lesz-e belőlük, az további kockázatot hordoz magában. Az új termékeket, technológiákat legtöbbször induló vállalkozások (startupok) kereteiben fejlesztik, amelyeknek elkülönült piacuk van, részesedéseik értékesítésre kerülnek.

Izrael gazdasága ennek a modellnek egyik mintagazdasága (ITR, 2021; MAFR, 2020). Hazai technológiai cégei fejlesztésére főként az Egyesült Államokból származó kockázati tőkét von be és az értékesíthető termékeket hordozó cégeit elsősorban az Egyesült Államok technológiai nagyvállalatai vásárolják meg (KPMG Enterprise, 2017; Maune, 2017). A Yozma program (Avnimelech, 2009) keretében megvalósult gazdasági modell sarokpontjai a korai fázisú (early stage) technológiafejlesztés, a kockázati tőke hálózatok alapok-alapja („fund of funds") jellegű felépítése, az alapok tulajdonosi hátterének felépítése során a külföldi menedzselési tapasztalatok becsatornázása, az Izraelbe áttelepült nagyszámú magasan képzett munkaerő hasznosítása. Izrael mellett - ugyan kevesebb sikerrel - Szingapúr (Völgyi, 2015) és Észtország is kísérletet tett a modell követésére, továbbá Kína és gazdag olaj alapú gazdaságok is kísérletet tesznek a modell meghonosítására.

\section{Növekedési modellek néhány specifikus jellemzóje}

Jövedelem plafon: Különböző növekedési modellek az értékláncban eltérő arányban érintenek különböző jövedelemszintű tevékenységeket. Az alábbi grafikon az értéklánc, mint változó függvényében mutatja a foglalkoztatás, a bértömeg és az átlagos, éves munkabér alakulását.

2. ábra: Foglalkoztatási és bértömeg szerkezet az értéklánc elemeiben (Egyesült Államok, feldolgozóipar, 2010)

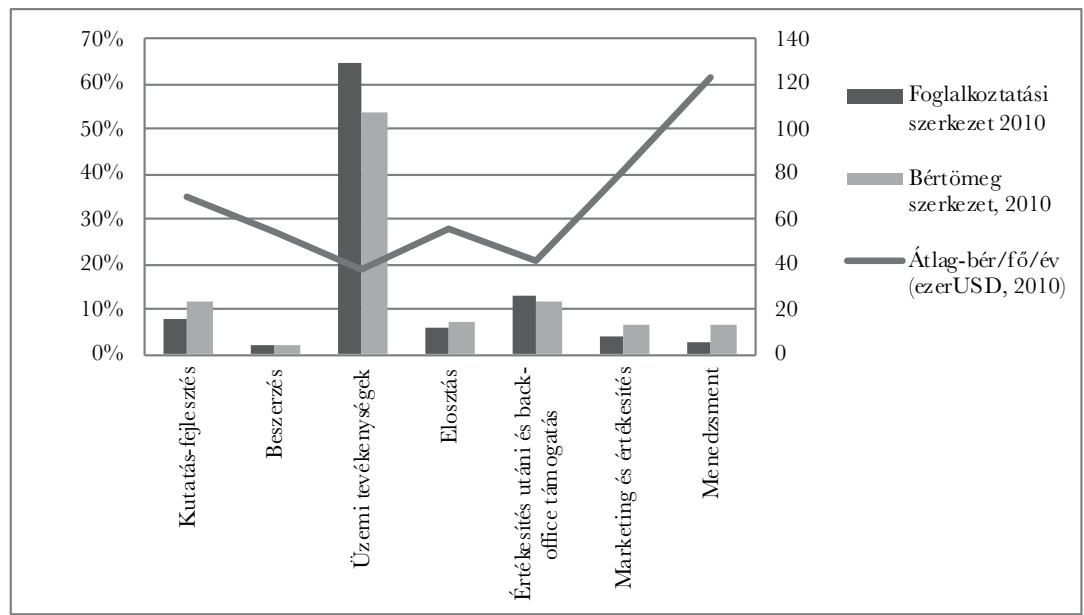

Forrás: McKinsey Global Institute, 2012 
A külföldi működőtőke kibocsátó és befogadó modell tevékenységi szerkezetét az egyik legalacsonyabb jövedelmet (bért) biztosító értéklánc elem dominálja. Az operatív tevékenységek jövedelme a legalacsonyabb a forrásgazdaság jövedelem viszonyai alapján, és különösen alacsony a célgazdaság jövedelemszintjén. A tőke kibocsátóknak ez jelentős megtakarítást jelent. Ennek azonban van egy következménye a befogadó modellre nézve. A kibocsátó gazdaságnak csak addig érdemes tőkét kihelyezni, amíg a befogadó gazdaság munkaerő költségei a kibocsátó gazdaság azonos tevékenységére jellemző munkaerő költségeinél alacsonyabbak. Ebből azonban - modellszerűen - az is következik, hogy a befogadó gazdaság jövedelem szintjének szignifikánsan alacsonyabbnak kell lennie a kibocsátó gazdaság jövedelem szintjénél, mivel a kibocsátó gazdaság értékláncában az operatív tevékenységnél magasabb jövedelmet biztosító tevékenységek súlya magasabb.

A működőtőke befogadó gazdaság munkajövedelme - ha az Egyesült Államok feldolgozóiparának foglalkoztatási szerkezetét a tényleges bérekkel, illetve az üzemi tevékenységek béreivel súlyozzuk - 82\%-a a kihelyező gazdaság munkajövedelmének. Ez a növekedési modellnek egyben a növekedési modell jövedelem plafonja. Hasonló jövedelem plafon becslést készíthetünk a kutatás-fejlesztési tevékenység által dominált gazdaságokra is, amelynél viszont a jövedelem korlát magasabb egy szervesen fejlett gazdaság átlagos jövedelem szintjénél.

\section{3. ábra: Foglalkoztatás tevékenységi szerkezete a feldolgozóipari szektorokban (Egyesült Államok, 2010)}

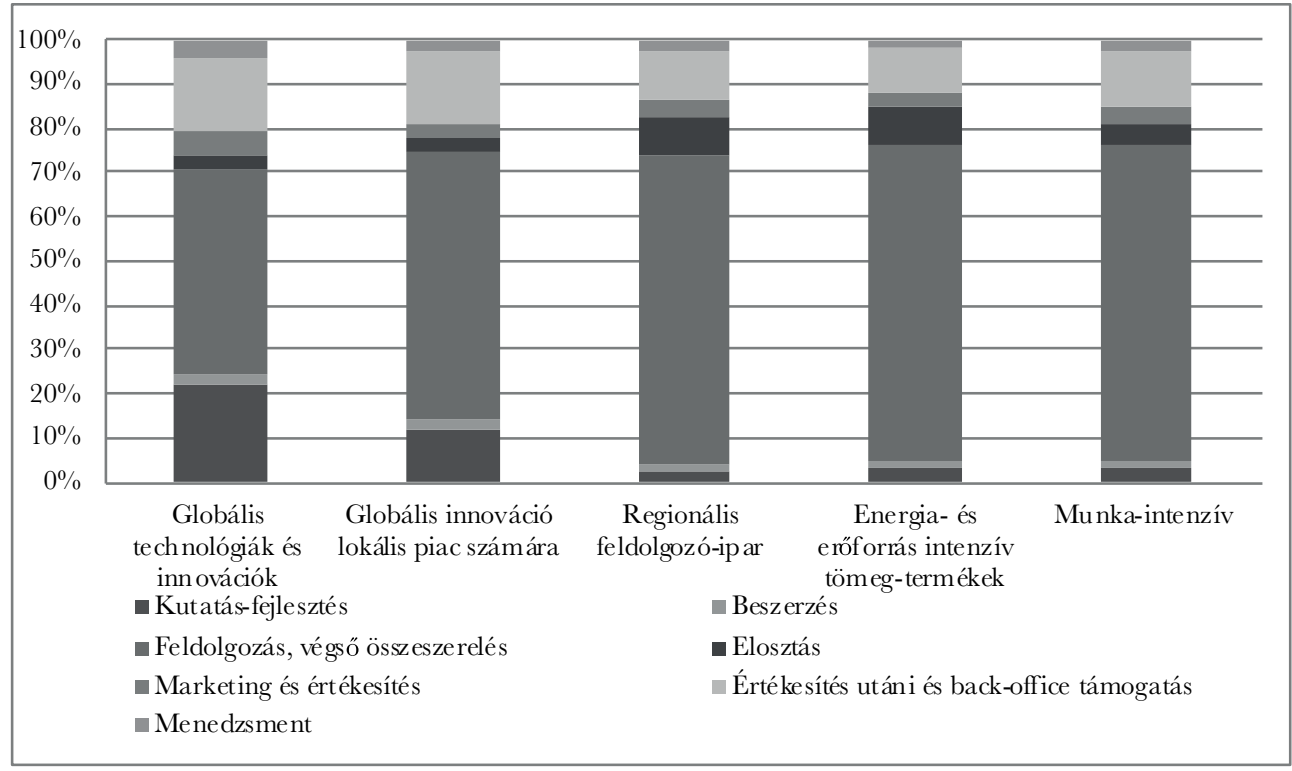

Forrás: McKinsey Global Institute, 2012

Beruházás-igényesség: A növekedési modellek különböző tőke eszköz igénye mellett tőkeigényének mértéke is jelentősen eltérhet. A növekedési ütem és az azokhoz kapcsolódó beruházási intenzitás között nem létezik és nem is létezhet „mechanikus” kapcsolat. A 
beruházási intenzitás megfelelő szintje a növekedés szükséges feltétele, de magasabb beruházási arány nem feltétlenül jár együtt magasabb növekedési ütemmel. Ésszerűnek tűnik, hogy egy tudásintenzív növekedési modell - a technológiák és a termékek fejlesztése, továbbá a piacokra való belépés költségei miatt - nagyobb beruházásigényt táplál, mint a stabil hátterű, minimális kockázattal történő működőtőke befektetések által dominált növekedési stratégia. Dél-Korea a gyors növekedési periódus alatt a 7,8\%-os átlagos növekedést átlagosan 30\%-os, amíg a közel azonos ütemben növekedő Írország és a fékezettebb ütemet mutató Finnország 20\%-os beruházási ráta mellett érte el.

Infrastruktúra igény: Az iparfejlesztés infrastruktúrái teljesen átformálták a vállalati értékláncok beszerzéssel és elosztással kapcsolatos elemeit. Ennek az infrastruktúrának az alapját a közlekedés, hírközlés, villamosenergia-ellátás, a szakmai oktatás és az ipari parkok rendszere képezi. Ezzel szemben a technológiai gazdaság infrastruktúrái az oktatás és a kutatás-fejlesztés köré összpontosulnak.

A technológiai gazdaság alapjai a félvezető termékek és technológiák létrehozásáig vezethetők vissza, amelyek tovagyűrűző technológiai, üzleti és növekedési hatásokat váltottak ki a nemzetgazdaságokban. A hetvenes évek második felében megjelentek a technológia-hordozó kisvállalatok, amelyeket kezdetben garázscégeknek később startupoknak neveztek. A folyamat kormányzati és üzleti alapú támogatására létrehozták a technológiai inkubátorokat. A kutatás-fejlesztés új modelljét a bürokratikus konglomerátumok nem voltak képesek bekebelezni, ezért a kiépülő új struktúra új finanszírozási intézményeket igényelt. Kifejlődött a kockázati tőkefinanszírozás, létrejöttek a specializált technológiai tőzsdék, illetve tőzsdei szekciók. A technológiai gazdaság tovább fütötte az outsourcing iránti igényt (külföldi működőtőke befektetés és relokáció), illetve az M\&A tranzakciókat, mint az országok közötti technológia transzfer eszközeit. A sikeres országok a nemzeti adórendszereket is bevetették a technológiai gazdaság fejlesztésébe, főként a kockázati alapokba történő magánbefektetések elősegítésére. Az egyetemeken kiformálódtak az ún. STEM (science, technology, engineering, math) tantárgycsoportok. A nagyvárosok technológiai parkjai szoros versenyben állnak egymással. A szolgáltatások volumenének és minőségének értékelésére kidolgozták a technológia centrumok minősítési rendszerét. Az eszközrendszer jelenleg is fejlődik: a technológia transzfer új intézménye, az ún. akcelerátor programok csak néhány éves múltra tekintenek vissza.

\section{A FOGALMAK FORMALIZÁLT ÖSSZEFÜGGÉSEI}

Az értéklánc, az üzleti és növekedési modell, az adaptáció, illetve a jövedelem függvény fogalmai formalizálhatóak.

Az értékláncokat a legegyszerűbben mátrixként (esetleg vektorként) ábrázolhatjuk (lásd 1. sz. táblázat), mivel a mátrixok a leginkább alkalmasak a jelenségek tömör leírására. A mátrix soraiban az értéklánc elemei, oszlopaiban az értéklánc elemeit alkotó tevékenységek meghatározott specifikus tulajdonságai találhatók. Az értéklánc mátrix formalizált jelölése az alábbi:

$$
\text { Él } \underset{\text { gazdasági szereplő }}{\text { tulajdonság }}
$$


A jobb felső index mutatja az értéklánc meghatározott specifikus tulajdonságát (tartalmát), például a tevékenységek szolgáltatási színvonalát, munkaigényét (bér, bértömeg), tőkeigényét (lekötött tőke állomány, értékcsökkenés), kutatás-fejlesztési kiadásait, stb. A jobb alsó indexben az értéklánc alanyiságáról találunk információt, például vállalat, szektor, nemzetgazdaság, élenjáró vállalat, követő vállalat, stb.

Az értéklánc homogenitási szintjét számos módon meghatározhatjuk. A homogenitási szint lehet az indikátorok átlagától való eltérés, minimum és maximum értékeinek eltérése, az értékek szórása, illetve alkalmazhatjuk a „leggyengébb láncszem elvét”, amikor az indikátorokat a legalacsonyabb értékével tekintjük azonosnak.

$$
\text { h gazdasági szereplő }
$$

Az értékláncok specifikus tulajdonságait korrigáljuk az értéklánc homogenitási értékével, amely magasabb homogenitási szintnél nagyobb, alacsonyabbnál kisebb szintet mutat.

Az értéklánc hosszúságát a nem nulla (gyakorlatban a meghatározott limit érték fölötti) értékkel rendelkező elemek száma mutatja meg a teljes értéklánc összes elemének arányában.

Az ún. átfordító értéklánc mátrix arra szolgál, hogy a különböző dimenziójú elemek tulajdonságai összehasonlíthatók legyenek. Ennek dimenziója lehet százalékos érték, illetve az annak megfelelő verbális minősítés: alacsony, közepes, magas, extra magas.

Az üzleti és növekedési modell az értéklánc elemek funkciói ellátására a lehetséges alternatívák közül kiválasztott modellek együttese. Matematikai értelemben az üzleti modell - a vállalkozó döntéseinek eredményeképpen - az alternatívák adta lehetőségek vagy kombinációk egy realizációja, amely megvalósítható és a vállalkozó szempontjai szerint a legelőnyösebb. Az üzleti és növekedési modell (lásd 2. sz. táblázat) jellemzői révén számszerűen is definiálható (például: növekedési jövedelem plafon, eltérő beruházás- és infrastruktúraigényesség).

$$
\mathbf{M}_{\text {gazdasági szereplő }}^{\text {modell típusa }}
$$

A növekedési modell a gazdaságra jellemző rendszer-változó, azonban egy gazdaságon belül szektoronként is eltérő lehet. A gazdasági modellek hatásai (lásd 3. sz. táblázat) azon változók összessége, amelyek változtatására a vállalkozó és a gazdaságstratégiai tervező üzleti és növekedési modelljei alkalmazásával törekszik. Ilyen változók lehetnek egy vállalat vagy nemzetgazdasági szektor piaci részesedése, árbevétele, költségei vagy likviditása.

Az értéklánc mátrixot az alkalmazott üzleti és növekedési modellek határozzák meg:

$$
\text { Él }{ }_{\text {gazdasági szerepló }}^{\text {tulajdonśa }}=f\left(\mathrm{M}_{1}, \mathrm{M}_{2}, \ldots \mathrm{M}_{\mathrm{n}}\right)
$$

Az üzleti szektorokban a követő vállalat bázis szintjét az élenjáró vállalat üzleti modelljének átvételével javítja. A követők új bázisa tulajdonság mátrixát a követők bázisa és az élenjárók üzleti modellje hatás index mátrixának Hadamard-szorzata ${ }^{6}$ adja.

$$
\text { Él } l_{\text {követő új bázis }}^{\text {tulajdonság }}=\mathrm{E}_{\text {követő bázis }}^{\text {tulajdonság }} \circ \mathrm{M}_{\text {élenjáró }}^{\text {tulajdonság index }}
$$


Ez a szorzat akkor képezhető, ha a két mátrix méretében és belső szerkezetében azonos felépítésű. Az azonos felépítés biztosítja, hogy a két mátrix megfelelő pozíciójú elemei kerüljenek összeszorzásra.

Az összes követő vállalat bázisa az élenjárók sorozatos innovációinak együttes hatását követően (d a szektor vállalatainak száma 1-től l-ig, t az idő 1-től k-ig):

$$
\text { Él }{ }_{\text {követỏ szektor új bázis }}^{\text {tulajdonság }}=\sum_{d=1}^{l} E \text { Él } 1_{\text {követő szektor bázis }}^{\text {tulajdonság }} \prod_{t=1}^{k} \mathrm{M}_{\text {élenjáró (t) }}^{\text {tulajdonság index }}
$$

A nemzetgazdaság adott értéklánc eleme tulajdonságainak változása az üzleti szektorok és a kormányzat tevékenységének hatásaiból tevődik össze.

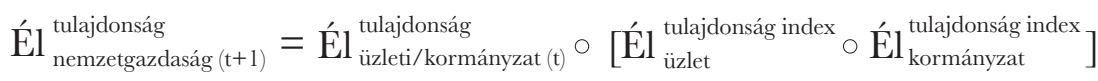

A nemzetgazdasági jövedelmet (kibocsátást) meghatározó tényezők:

$$
\mathrm{Y}=f\left[\mathrm{~K}, \mathrm{~L}, \mathrm{Kn}, \mathrm{N}, \mathrm{E}\left(\mathrm{E}_{\text {üzlet }}^{\text {tulajdonság }}, \mathrm{E}_{\text {kormányzat }}^{\text {tulajdonság }}, \mathrm{h}_{\text {üzleti/kormányzat }}\right)\right]
$$

A nemzetgazdasági jövedelem akkor a legmagasabb, ha a kulcsszektorokban

- a növekedési modell erőforrás-ellátása (tőke, munka, tudás, természeti erőforrások) magas,

- $\quad$ az üzleti szektor - és az ahhoz kapcsolódó kormányzati támogatás együttes - szolgáltatási színvonala (olyan növekedési modellt alkalmaznak, amelynél annak jövedelem plafonja magas, illetve a fajlagos tőkeigény optimális), az értékláncok homogenitása magas.

\section{ÖsszeGZÉS}

Az üzleti és az azt támogató növekedési modellek alapvetően befolyásolják a termelési tényezők hatáskifejtését, azok gazdasági növekedéshez való hozzájárulását. Az üzleti irodalom több száz üzleti modellt azonosított már, amelyet a vállalkozók gyakorlati célokra, az eredményesebb üzleti stratégiák létrehozása céljából dolgoznak ki és alkalmaznak. Az üzleti- és növekedési modelleknek azonban helye van a mikro- és a makrogazdaság növekedéssel kapcsolatos vizsgálódásaiban is. Ezért a modellek értelmezése, rendszerezése és formalizálása válik szükségessé. Az értelmezés egyik alapvető eszközét az értékláncok - több évtizedes múltra visszatekintő, szintén gyakorlat orientált - irodalma szolgáltatja. 


\section{JEGYZETEK}

1 A McKinsey Global Institute (2012) tanulmánya az Egyesült Államok feldolgozóiparát öt szektorra bontja (globális technológiák és innovációk, globális innováció lokális piac számára, regionális feldolgozóipar, energia- és erőforrás-intenzív tömeg-termékek, munka-intenzív termékek) és szektoronként bemutatja a termelési tényezők (technológia, a tőke- és munkaigény) hozzájárulásait a hozzáadott értékhez. (McKinsey Global Institute, 2012)

$2 \mathrm{~K}$ - (capital) tőke, L - (labour) munka, Kn (knowledge) - tudás, E (entrepreneurial capabilities) - vállalkozói képességek, $\mathrm{N}$ (natural resources) - természeti erőforrások

3 Kiemelendő, hogy kétféle munkaintenzív gazdaság létezik. Egyrészt a feldolgozóipar leginkább munkaerőgényes szegmensét nevezzük annak, másrészt a külföldi működőtőke bevonó gazdaságokat is, amelyek a tőke kihelyező vállalatok értékláncainak üzemi tevékenységeit látják el. Ezek a fogadó országok a magas hozzáadott érték forrásait létrehozó tevékenységekkel nem rendelkeznek, a tőkevonzás érdekében az üzemi tevékenységek munkaerő, oktatási, logisztikai hátterét biztosítják.

4 A ,reverse engineering” a termékek jellemzőiből az azt létrehozó technológiai folyamat visszafejtése, amit a felzárkózásuk eszközeként elsősorban a kelet-ázsiai gazdaságok alkalmaztak és alkalmaznak ma is.

5 Az "early stage" a "seed" és a "later stage" között elhelyezkedő vállalkozásfejlesztési periódus. Ebben a szakaszban kezdődik el a termelés, illetve ekkor kezdenek realizálódni az első értékesítési eredmények. Ezt követi a "growth/ expansion stage", amely már a tőzsdei bevezetésre való előkészületeket is magában foglalhatja.

- A matematikában a Hadamard-szorzat - más néven Schur-szorzat, vagy elemenkénti szorzat - egy kétváltozós művelet, aminek tényezői ugyanolyan dimenziójú mátrixok. A szorzatban álló elemek a tényezők megfelelő elemeinek szorzatai.

\section{FelHasZnÁlt irodalom}

Avnimelech, Gil (2009): VC policy. Yozma Program 15-Years perspective (https://www.researchgate.net/publication/228921726_VC_Policy_Yozma_Program_15-Years_perspective

Barry, F. - Görg, H. - McDowell, A. (2001): Outward FDI and the Investment Development Path of a Late-Industrialising Economy: Evidence from Ireland (https://researchrepository.ucd.ie/bitstream/10197/1255/1/WP01.08.pdf)

Barry, F. - O'Mahony, C. (2006): Making Sense of the Data on Ireland's Inward FDI (https://www.econstor.eu/bitstream/10419/72308/1/521069599.pdf)

Case study: Dell - Distribution and supply chain innovation (https://learn.marsdd.com/article/case-study-dell-distribution-and-supply-chain-innovation/)

CIA (1983): South Korea, Economic Decision Making in Transition, CIA, Directorate of Intelligence. 1983. januar

Dallos, Michall (2021): Busines Model Evolution (https://businessmodel.company/business-model-evolution/)

Fakir, A. E. (2016): South Korean System of Innovation: From Imitation to Frontiers of Technology, Successes and Limitations

Faludi Péter (2005): Pak Csong-Hi gazdasági programja - a modernizáció gazdaságpolitikája Dél-Koreában, Kül-Világ 2005/4., 24.o.

Fourweekmba (2021): What Is a Business Model? 54 Successful Types of Business Models You Need to Know (https://fourweekmba.com/what-is-a-business-model/)

Hirvonen, T. (2004): From Wood to Nokia: The Impact of the ICT Sector in the Finnish Economy, ECFIN country focus (https://ec.europa.eu/economy_finance/publications/ pages/publication 1417_en.pdf)

Ireland, D.F. (2014): Economic Impact of the Foreign-owened Sector in Ireland, Department of Finance

ITR (2021): The Israeli Tech Review Q1 2021., Presented by IVC Research Center and Meiter Law Office (https:// www.ivc-online.com/LinkClick.aspx?fileticket $=$ elxRgCjBtZw\%3d\&portalid=0\&timestamp=1618166486915)

Kiander, J. (2004): The evolution of the finnish model in the 1990s: From depression to high-tech boom (https://core.ac.uk/ download/pdf/153491783.pdf)

Kim, L. (1997): Imitation to Innovation, The Dynamics of Korea's Technological Learning, Harvard Business School Press 
Kim, Westney (1999): Technology and Korea's Business Systems in Action (Revised 1999 -forthcoming in Continuity and Change in Asia's Business Systems), Linsu Kim, Korea University D.; Eleanor Westney, MIT Sloan School of Management

KPMG Enterprise (2017): Venture Pulse Q4 2016, Global analysis of venture funding https://assets.kpmg/content/dam/ $\mathrm{kpmg} / \mathrm{xx} / \mathrm{pdf} / 2017 / 01 /$ venture-pulse-q4-2016-report.pdf)

MAFR (2020): Most Active Funds Report 2020

Maryville University (2021): Traditional Types of Business Models (https://online.maryville.edu/business-degrees/traditional-types-business-models/)

Maune, A. (2017): Developing Competitive advantage through startups and venture capital in emerging markets: A view from Israel

McKinsey Global Institute (2012): McKinsey Operations Practice. Manufacturing the future. The next era of global growth and innovation. 2012. november (https://time.com/wp-content/uploads/2015/03/manufacturing-the-future.pdf)

OECD (2015): Policy Lessons from Financing Young Innovative Firms 2015. (https://www.oecd.org/officialdocuments/ publicdisplaydocumentpdf/?cote=DSTI/IND $(2014) 5 /$ FINAL\&docLanguage $=$ En $)$

OECD (2019): Global Value Chain Development Report 2019, Technological Innovation, Supply Chain Trade, and Workers in a Globalized World (https://www.oecd.org/dev/Global-Value-Chain-Development-Report-2019-Technological-Innovation-Supply-Chain-Trade-and-Workers-in-a-Globalized-World.pdf)

Paija, L. (2000): ICT Cluster - The engine of knowledge-driven growth in Finland (https://www.etla.fi/wp-content/uploads/2012/09/dp733.pdf)

Porter, Michael E. (1985): Competitive Advantage Creating and Sustaining Superior Peifonnance (https://imarcai.com/ wp-content/uploads/2019/04/Porter-1985-chapter-1.pdf)

Startup Genome (2019): Global Startup Ecosystem Ranking 2015, 2017, 2019 (https://startupgenome.com/reports/ global-startup-ecosystem-report-2019)

Völgyi Katalin (2015): A sikeres államkapitalizmus példája - Szingapúr, 2015. december (https://mek.oszk. hu/15900/15991/15991.pdf) 